\title{
Relationships between deflector faults, collapse dolines and collector channel formation: some examples from Slovenia
}

\author{
France Šušteršič ${ }^{I}$
}

\begin{abstract}
:
Šušteršič F. 2006. Relationships between deflector faults, collapse dolines and collector channel formation: some examples from Slovenia International Journal of Speleology, 35 (1), 1-12. Bologna (Italy). ISSN 0392-6672.

In some Slovenian caves collector channels gather sinking underground streams and redirect them for potentially long distances parallel to certain faults. The collector channels formed due to ongoing long-term collapse of cave roofs at the points where passages break through the faults, which function as a kind of screen and are termed deflector faults. The fault trends are marked by collapse within the caves, and by active collapse dolines at the surface.
\end{abstract}

Keywords: speleogenesis, collector channel, deflector fault, collapse, collapse doline, karst of Slovenia

Received 21 May 2005; Revised 27 May 2005; Accepted 18 October 2005

\section{INTRODUCTION}

Klimchouk and Ford (2000, p.47) wrote: "Speleogenesis can be viewed as the creation and evolution of organized permeability structures in a rock that have developed as the result of dissolutional enlargement of an earlier porosity." In the same volume Lauritzen and Lundberg (2000, pp.408-409) added the following, in slightly different order, to the same idea: "In the strict sense (sensu stricto), 'speleogenesis' means the creation of a cave from 'scratch'." ... "Once speleogensis has established the gross geometry of cave system..." ... "When discussing the shape of caves, it is practical to distinguish between mesoforms, that are similar size to the diameter of the cave passage itself, and microforms, that are smaller than the passage." ...

"Meso- and microforms are controlled by corrosive and erosive processes (active variables) but have lithologic and tectonic constraints (passive variables) ${ }^{1}$. Geology influences passage form through control of..."

This raises some questions:

-What is "the gross geometry of a cave system", and/or what (perhaps) are macroforms?

-What controls the development of the gross geometry of a cave system or, in other words, the structure of the cave system, and how is this achieved?

-Does a conduit pattern simply adjust itself to the constraints imposed by passive variables, or does

I- Dept. of Geology NTF, University of Ljubljana, SI-1000,

Ljubljana, Aškerčeva 12, Slovenia.

E-mail: france.sustersic@ntfgeo.uni-1j.si it react actively to the various situations that may appear during development?

When searching for the answer to the first question, it becomes self evident that the formation of a conduit system proceeds on two logical levels:

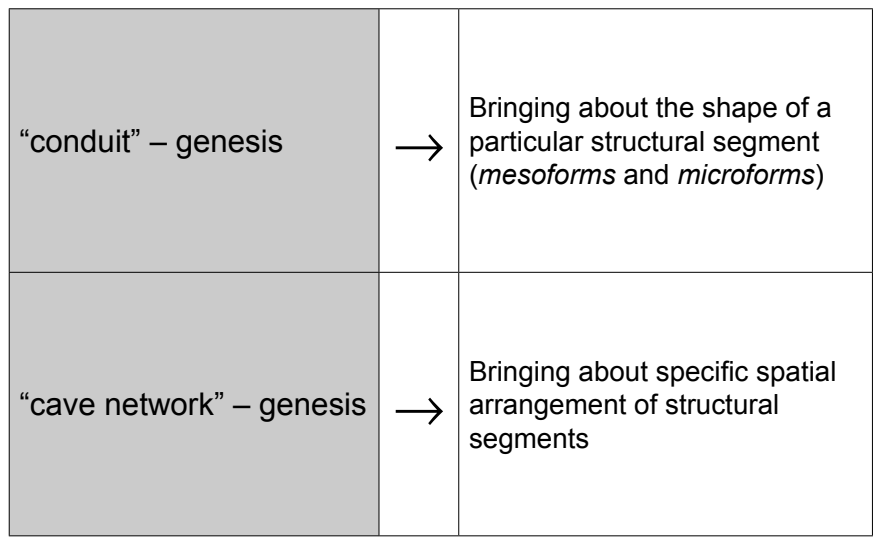

In this context, the latter notion appears to be the answer to the first question.

The former aspect has been clarified extensively during the last decade, and the book edited by Klimchouk et al. (2000) provides very convincing proof

${ }^{1}$ The same concept was proposed by Šušteršič (1979) as a purely theoretical background for mathematical modeling of cave conduit cross sections, and "active" and "passive" variables were termed factors. 
of this. On the other hand, the latter logical level has been rather less elaborated. Palmer (2000), however, demonstrated that cave pattern develops under direct and predictable control of general hydrogeological circumstances what typically belong to active factors (variables) in the sense of the previous discussion. Considering passive control, most researchers appear to believe that, within the borders of the aquifer, at the resolution of a square kilometre or so, evolution proceeds straightforwardly from privileged fissures and/or bedding planes towards the conduit pattern.

At wider resolutions, however, the relationships seem not to have been considered so clearly. It appears that researchers have been more concerned with the dynamics of the whole underground water body than with the behaviour of individual cave passages, which are generally treated simply as "caverns". Nevertheless, some specific, well-supported studies exist (e.g. Lowe, 1993, 2002). Except for certain extreme situations (see, for example, Ford and Williams, 1989, 40, Fig. 2.12) this leads investigators to at least suspect that macroscale geological guidance depends upon local tectonic conditions to such an extent that any extrapolations, or generalizations must be very cautious. So, the situation discussed in the present paper may be regarded as a quite specific product of relatively pure karstification ${ }^{2}$ and specific tectonic development close to the border zone of the rotating Adriatic subplate and the Eurasian craton (Vrabec and Fodor, 2005).

Recent study of "active"3 collapse dolines (Šušteršič, 1997 ; 2000b), and of the role of "deflector faults" and "collector channels" (Šušteršič et al., 2001), revealed that:

- Processes intrinsic to (some) cave systems bring about predictable organization of conduit networks;

- These processes are partly reflected at the surface.

Looking at the actual geological setting it is possible to predict the pattern of the caves from the initial geological conditions. With enough field information, plus an understanding of the geological history of the region, it should be possible to predict where caves will form (or at least to explain why they formed where they did).

${ }^{2}$ The local, Mesozoic carbonate succession reaches nearly $7 \mathrm{~km}$ in thickness and is perhaps the thickest in the world. Additionally, limestone purity locally achieves 99.99\% $\mathrm{CaCO}_{3}$.

3 The present author entitled his (1997) paper:

Rakovska kukava - collapse or tumour doline? The latter expression (tumour doline) was coined in a rather poetical way. In Waltham et al. (2005, p.59) the term

tumour doline is adopted as a standard technical term. To maintain consistency with his earlier work, in the present paper the author retains his original terminology ("active" dolines), whereas the further use of either term is at the discretion of the karstological community.

\section{STARTING IDEAS}

In 1965 Gams noticed that large cave channels run parallel to the linear margins of some Slovenian poljes, collecting water that drains perpendicular to the polje border into the karst. He termed them collector channels ${ }^{4}$.

A particularly well-preserved channel on the outflow side of Cerkniško polje follows the polje margin for more than two kilometres. To the present author's knowledge, neither Gams nor other workers - with the exception of Šušteršič et al., 2001 - have developed his ideas further.

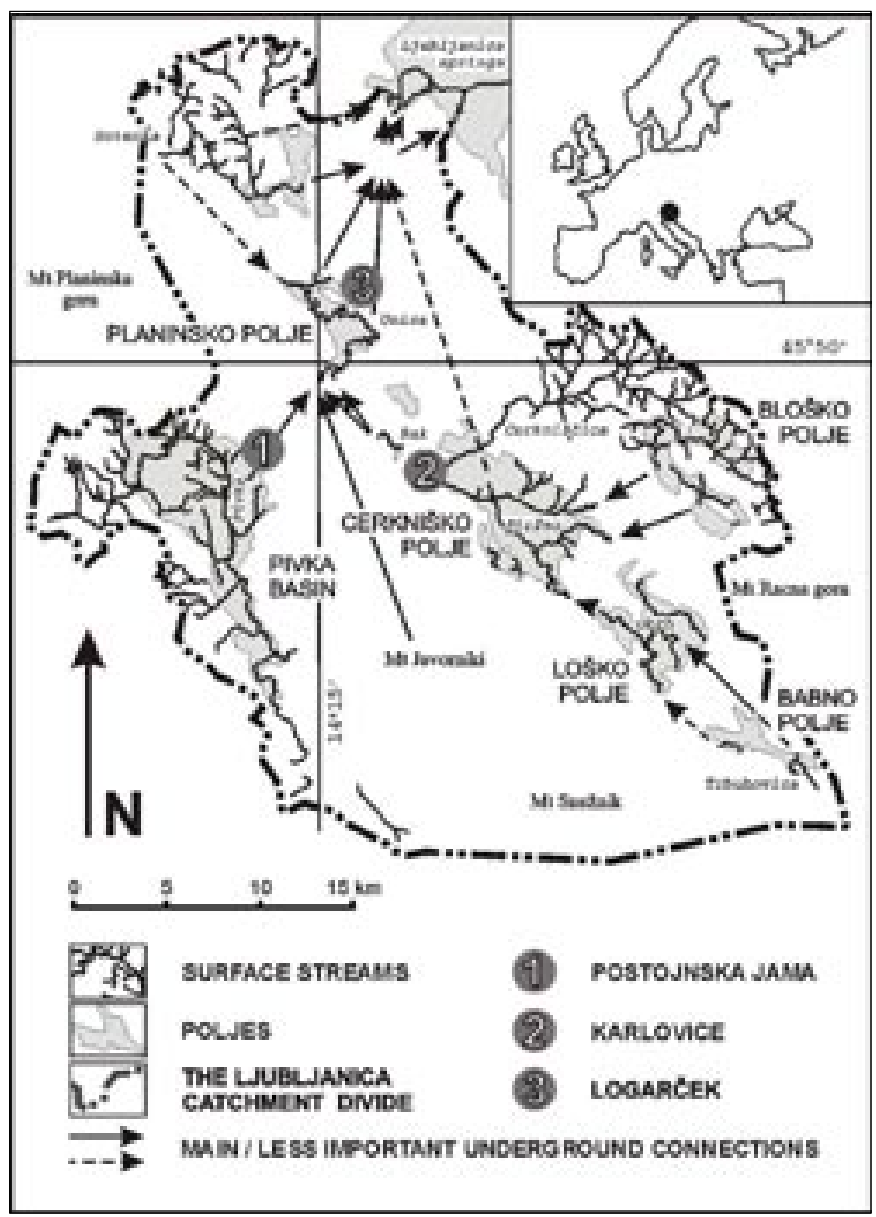

Fig.1. General location of the studied sites.

Detailed geological mapping of cave systems and the terrains above them during the last few decades (Gospodarič, 1970; Čar 1982; Čar and Gospodarič, 1984; Čar and Šebela, 1997; Šebela 1998; Šebela and Čar, 1991; Šušteršič, 1997; Šušteršič et al., 2001) has revealed a very strong connection between cave channel formation and tectonic deformation. The causal/consecutive relationships are to some extent dynamic and they may differ during particular stages of flow corridor ${ }^{5}$ development. Transformation of particular fault zones, induced by progressive

4 In the English summary Gams did not mention collector channels directly, as he was focusing on other topics. The present English term "collector channel" was first used by Šušteršič et al. (2001), according to the suggestion of Dr David J. Lowe. 
underground and surface karstification, led to the concentration of relatively diffuse polje outlets into one master stream, parallel to the fault, and eventually to the formation of the collector channel. Thus, collector channels are an outcome of specific geospeleological conditions/development not far from the outflow polje border.

According to the authors cited above, the faults in question are of sub-regional and local dimensions. The displacements are within the range of several dozen metres. The properties of rock injured by fracturing vary characteristically. If the zone is only a few metres wide, the rock is crushed into fragments of large cobble to pebble size, and these are enclosed and supported by a matrix of generally uncemented tectonic silt. The colour is intensely red, partly due to terra rossa admixture, and partly due to the transformation of goethite into hematite, driven by tectonic stress (Zupan Hajna, 1995). On the surface these locations are generally marked by intensely vegetated stripes, by less well-expressed linear depressions or even by bogazes. According to Čar (1982) such zones are virtually impermeable.

Along their length such features commonly expand to form hundred metre or so wide stripes of shattered rock. Clints or formless piles of boulders stick out of the ground. However, when hit with a geological hammer such rock, which may be highly recrystalized and interdigitated with red patches of hematite, breaks into small pieces. According to the same author such zones are highly transmissive. Sectors of both types of injury alternate quite regularly, in accordance with the local (palaeo-) stress field (Čar and Šebela, 1997). If the zones become tectonically stable they appear to be quite prone to re-cementation. The alternating nature of shattered and recrystalized rock can also be detected in caves, so that it may be concluded that the alternating pattern is three-dimensional.

Larger scale karst subsidence phenomena, known generically as collapse dolines (Cramer, 1944, p.327; Sauro, 2005, p.117), were long ago recognized as the most likely surface karst features to give direct information about underground development. By reference to the example of Rakovska kukava, Šušteršič (1997) demonstrated that very large collapse dolines can evolve from relatively small cave chambers (type O2, Šušteršič, 2000b, p.222, Fig.4). Detailed study of the doline's morphology revealed that its volume and its present shape are predominantly the result of the

\footnotetext{
${ }^{5}$ In this paper, the expression flow corridor determines the portion of the saturated zone where the main quantity of ground water is moving relatively quickly, following the local [hydraulic] gradient, regardless of the proportions of enlarged fissure flow and elaborated channel flow. In the other words, the flow corridor is the portion of speleogenetic space with ongoing active speleogenesis. If not disturbed, positive feedback processes exist within a flow corridor, supporting the concentration of flow into a small number of large conduits.
}

simple settling of tectonic crush within the shatter zone of a local strike-slip fault, plus slope processes. The explanation is that underground water finds such zones difficult to break through. Consequently, once such a route was opened, flow along it would persist, even if the passage were repeatedly obstructed by periodic collapse of tectonic crush. This process would continue until the water could no longer cope with the increasing input of collapse material originating from the expanding doline slopes. Such dolines are described as active. Then the river would have to find another breakthrough location, which would be similarly unstable.

This paper sets out to reveal interrelationships between collector channels, the sub-regional tectonic setting and the "active" collapse dolines. It will be demonstrated that the collector channels are not just the outcome of arbitrary local conditions, but that they form under strong, though indirect, tectonic guidance. Collector channels in Postojnska jama and in Karlovice had been mentioned by Gams (o.c.), whereas the situation at Logarček (Planinsko polje) is somewhat more complex, and has only recently been recognised. New discoveries in 2003 proved the existence of cave passages approximately on the locations, predicted in the earlier paper (Šušteršič et al. o.c., Košir 2003 pers. comm., Pristavec 2003 pers. comm.).

\section{STUDIED EXAMPLE SITES}

The three caves discussed in the following text are direct or indirect drains of the Postojna basin, Cerkniško polje and Planinsko polje (Fig. 1).

All of them belong to the Ljubljanica sinking river catchment, which is the main drain of the inner part of the Classical Karst of Slovenia (Šušteršič, 2000a). The Ljubljanica is widely known as a string of surface and underground stream segments, with the streams emerging into closed basins that more or less fit the traditional view of poljes. Traditionally the river is divided into two branches.

The bulk of the western part encompasses the Pivka basin, which is in fact an endorheic basin predominantly on flysch (i.e. non-karstic rock) that drains underground. Nevertheless, it has many characteristics of a karst polje and thus, it has traditionally been regarded as one of them. On the other hand, the poljes of the eastern branch plus the Planinsko polje, which can be considered as the confluence of the two branches, are formed in karstic rocks. The final spring of the Ljubljanica River is a dozen kilometres north of Planinsko polje, close to Vrhnika town.

The parent bedrock in the area is predominantly Cretaceous limestone. The main tectonic structure is the Late Tertiary Idria Fault, which runs all along the eastern branch of the Ljubljanica poljes in a northwest - southeast direction. It appears, however, that the important structures in the context of the present paper are older than the Idria Fault. 


\section{Case 1: Underground flow of the Pivka (Fig.2)}

Postojnska jama cave is the main drain of the Pivka basin, lying in its northeastern corner. The system has several entrances, which were originally explored separately and eventually connected during the course of exploration. Thus, particular parts of the system have their own original names. Massive input of flysch gravel has brought about the formation of a cave maze on two main levels. "Dry" parts of the cave, partly modified for tourist visits, are very clearly separated from the active parts not far from the present cave entrance. Controlled much more by their actual accessibility than by the intrinsic organisation of the system, the dry passages are predominantly directed northwards. On the other hand, the active channel of the Pivka obviously turns northwestwards (Fig.2). It maintains this direction without significant deviation for nearly a kilometre, until it reaches a depth $25 \mathrm{~m}$ beneath the dry passage of Otoška jama. After a quarter of a kilometre, almost exactly beneath its entrance, the Pivka channel turns northeastwards. The cave ceiling's thickness ranges between $40 \mathrm{~m}$ to $60 \mathrm{~m}$ without displaying any particular pattern.
Though very irregular in detail, the Pivka passage runs in a reasonably straight line from the ponor towards and beneath the Otoška jama entrance. Compared to the predominantly large passages of the upper, dry, level, the active conduits, especially those closer to the bend, are narrower and lower. Incised phreatic loops can be seen at many locations, providing evidence that the channel is a product of a sinking river, laden with flysch gravel, that reshaped the initially phreatic system into an epiphreatic conduit. From the west, i.e. from the direction of the Pivka basin, a few underground tributaries join the underground river, justifying the attribution of the term collector channel (Gams, 1965, p.87 / in the Slovene text only).

Parallel to and some 50-100 m northeastward of the collector channel, Šebela (1998) noted a fault zone with a pervasive crushed zone. The fault has a characteristically Dinaric trend and can be traced underground as well as on the surface. Nevertheless, it is parallel to the normal contact between the limestone and the overlying flysch, so that its formation may not be attributed automatically to the "Idrian" tectonics. In the final $200 \mathrm{~m}$ before the Pivka breaks through

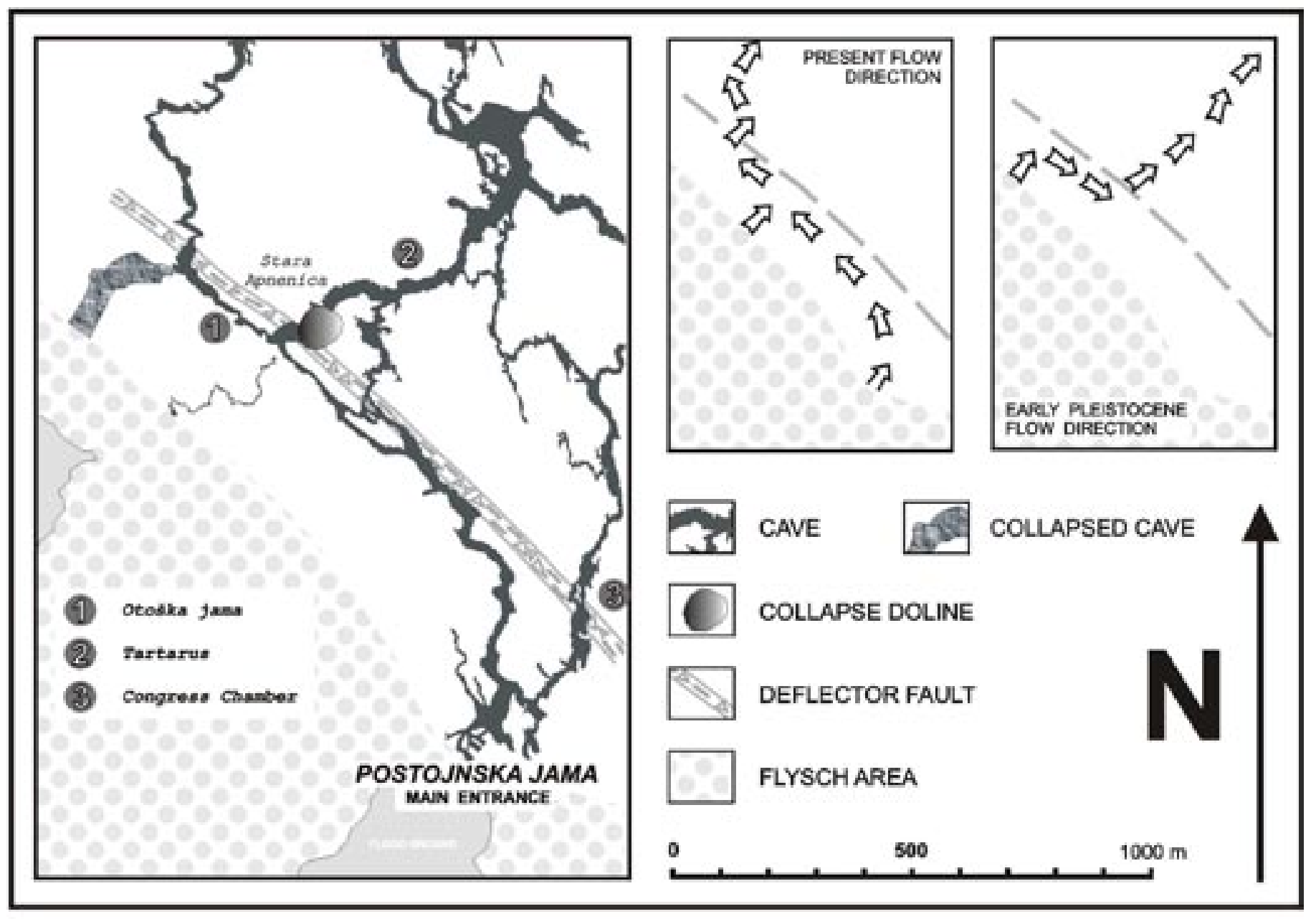

Fig.2. Geological and speleological details of the northwestern sector of the Pivka basin. Note that Otoška jama lies directly above Postojnska jama streamway. 
the obstacle, the number of locations that become siphons at higher water level increases.

Entering the outer fault zone, the channel becomes lower and narrower. Beyond the point where the passage direction becomes perpendicular to the fault and it penetrates its inner zone, it changes to a high and wide chamber. Essentially the ceiling is less selfsupporting, and fallen slabs protrude from the water. The river is still capable to remove the debris, but the rapids (Michler and Hribar 1959, p.167) indicate that it has reached the limit of its transportational/ erosional capacity.

Examination of locations where dry passages intercept the same fault trend, reveals comparable details. In the extreme south, Congress Chamber lies exactly where the tourist passage crosses the fault. Thick flowstone cover indicates that the ceiling has achieved stability and blocks are no longer collapsing. The richly decorated ceiling also shows that the water that passes through it has acquired excess carbonate. This is obviously due to the increased surface area that the water encounters when pouring through the fault shatter zone, and perhaps also due to more abundant vegetation on the surface.

The next point where the active river cave is linked to the "dry" cave is in the system of passages known as Tartarus, half a kilometre to the northwest. Tartarus consists of two main branches. The Upper Tartarus is obviously a continuation of Otoška jama, which was, in turn, the main ponor of the Pivka Basin during the Early Pleistocene (Gams, o.c.; Gospodarič, 1976). The Lower Tartarus is a swarm of narrow, labyrinth-like passages, presently connecting the Upper Tartarus with the active river cave. The nature of the passages of the Lower Tartarus indicates the difficulties that the river encountered when making its way through the broken zone. Here the flow did not persist for very long, and the span of the ceiling did not over-reach its stability.

Only a few metres beyond, where the fault zone and the large (20 m-wide, $15 \mathrm{~m}$-high) chambers of the Upper Tartarus intersect, the situation changes radically. The connection of the Upper Tartarus with the former ponor (Otoška jama) is choked by a collapse doline known as Stara Apnenica (Vol.: $31 \times 10^{4} \mathrm{~m}^{3}$ / Stepišnik, 2005, pers. comm..). As Fig.2 (inset) shows, just before reaching the fault zone the early Pivka turned southeastwards, in a direction 180 degrees from that of the present stream, and flowed through the present Otoška jama, along the fault for about 300 $\mathrm{m}$. Eventually, the stream turned perpendicular to the fault zone and broke through it. The large profiles of the passages indicate that the river flowed there for quite a long time. At the breakthrough point in the core of the fault zone, the roof fell down. Eventually, this brought about formation of the Stara Apnenica collapse doline (Gospodarič, o.c.). Farther towards the northwest no further dry passages are known intercepting the fault zone.

Due to the varying mechanical properties of the fault, "reactions" of the cave system at its interception with the fault are different, but it is evident that, in the past as well as at present, the roles were the same. The fault zone was once such an effective obstacle that, during its geological history, it diverted the river in two opposite directions, assuming that the regional orientation of the hydraulic gradient was approximately the same throughout.

\section{Case 2: Karlovice system (Fig.3)}

At present the Karlovice system is the main outlet cave of Cerkniško polje. It is a composite of interconnected caves with separate entrances, but evidently all belonging to the same system. The total length of explored passages is about $8 \mathrm{~km}$ and it gives an impression of a well-defined "horizontal" cave. During the last $50 \mathrm{ka}$, the Cerkniščica river brought its mechanical load into the cave and filled the lower parts of the tier with sediment. At the same time "antigravitational" erosion (paragenetic erosion) cut some upward phreatic loops. Eventually the main passages acquired epiphreatic characteristics. The master string of channels, built up of segments of heterogeneous origin and oriented in various directions, runs approximately 100 to $200 \mathrm{~m}$ away from and parallel to the ponor margin of Cerkniško polje, virtually perpendicular to the Dinaric direction. The stretch between the southern extension of Mala Karlovica cave and the Labyrinth in Velika Karlovica cave is nearly $2 \mathrm{~km}$ long. The cave ceiling above the channels described above is about $60 \mathrm{~m}$ thick, thickening to $70 \mathrm{~m}$ in the area of the Sujca dolines.

The polje border in this segment is predominantly precipitous (walls up to $40 \mathrm{~m}$ high) and surprisingly straight. Whereas the former property can be explained by possible corrosional undercutting of the border of the polje (Gams, o.c.), the latter unambiguously indicates a tectonic origin.

During detailed mapping of the cave passages Gospodarič (1970) established that several minor faults guide the direction of particular structural segments. Unfortunately, due to relatively difficulty of access he could not interpret these in greater detail. Čar and Gospodarič (1984) mapped the whole area between Cerkniško and Planinsko polje on the 1:5000 scale. Half a kilometre northwest from the polje border, and a few hundred metres northwest from the collector channel, they found an important crossDinaric fault with a wide shatter zone. Perhaps it is an equivalent of the pre-Dinaric, similarly trending faults detected in Postojnska vrata (the Postojna gap) by Čar and Gospodarič (o.c.). Due to its structural, hydrogeological and speleological importance Šušteršič et al. (2001) proposed the name Karlovice Fault (Fig.3). Even a short glance at the cave plan reveals the great influence that the fault exerted upon formation of the cave maze. 

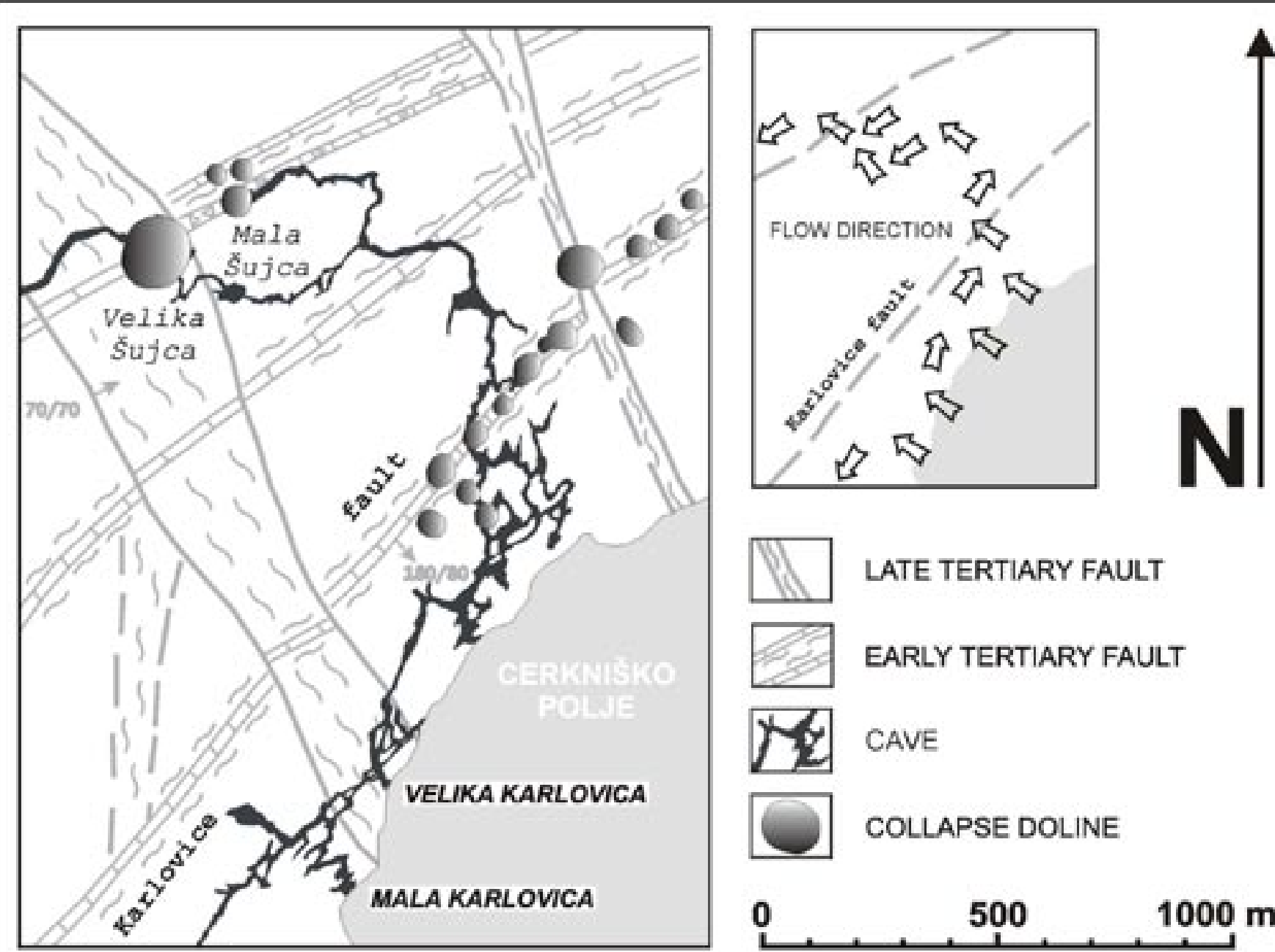

LATE TERTIARY FAULT

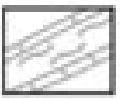

EARLY TERTIARY FAULT

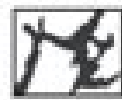

CAVE

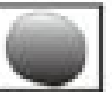

COLLAPSE DOLINE

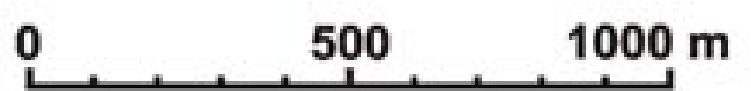

Fig. 3. Geological and speleological details of the Karlovice system.

In its southeastern sector, the collector channel runs nearly straight, parallel to the fault. Several tributary passages join it from the southeast, some of them through passages accessible to humans. Towards the northwest, i.e. towards the fault, some now-abandoned channels, predominantly interrupted by frontal collapses, branch off. At its extreme northwestern extension the channel changes into a highly complex maze, which extends in both horizontal and vertical planes. Here, too, most of the passages that lead towards the fault are cut by frontal collapses. Some of the collapses extend to the surface, bringing about the formation of collapse dolines. A few of these appear outside the known cave "influence area", towards the northeast.

Major quantities of water, associated with the collector channel continuation, cross the fault through only two channels. The southern one conducts water into the continuation of the cave, whereas an unexplored siphon interrupts the northern one, before the fault zone can be reached. In the former, ceiling collapse marks the point where the passage touches the core of the fault zone. The absence of a larger chamber perhaps indicates that this breakthrough position is relatively recent. Additionally, a half dozen relatively small (up to $50.000 \mathrm{~m}^{3}$ ) collapse dolines, ranged along the same fault on both sides of the present breakthrough location (Fig.3), testify that the situation is not time persistent.

After having broken through the fault zone, the cave turns towards the west, until it encounters the frontal collapses at the base of the collapse dolines Velika Šujca and Mala Šujca (Habič, 1967; Žalec et al., 1997). The situation there is quite similar to that before the trunk channel breaks through the Karlovice Fault. Again, a wide fracture zone of an early Tertiary fault (Šujce Fault), diverting the stream northwestwards, interrupts the free drainage of the underground river. Before the meeting, in the neighbourhood of the Sujice collapse dolines, the previously united stream splits into two separate channels, and part of the southern one is labyrinth-like. Therefore, both fault zones partly impede the underground stream and deflect it away from the straight-line direction towards the resurgence in the Rakov Škocjan valley. In contrast to the previous situation, the large volume of Velika Šjica $\left(6 \times 10^{5} \mathrm{~m}^{3}\right.$ / Stepišnik 2005, pers. comm.) indicates that the Sujice Fault is a greater obstacle to the underground water than the Karlovice Fault, and this made the stream keep to the breakthrough location for much longer.

So, the nature of the obstacles becomes clear. Whereas the fault zones are not completely waterproof, mechanically the shatter zone is so weak that it cannot sustain the formation of larger caverns. Cave roofs fall down and choke the caverns at the breakthrough 
locations. Gradually, the stream is deflected along the fault zone, making use of less important parallel fractures, until the sinking river finds another location suitable for breakthrough.

\section{Case 3: Logarček (Fig.4)}

Before the discovery of the inner parts of Najdena jama, Logarček had been deduced as being the "main outflow cave" of Planinsko polje, though it is not accessible directly from the polje, and it is ignored by the permanent stream of the underground Unica. Known parts of the system stretch on two main levels. The upper one is "dry" and is of no further interest in the context of the present paper. An epiphreatic passage known as the "Main Channel" dominates the lower part of the cave. It lies a few metres below the level of Planinsko polje, winding its way from close to the polje for nearly $2 \mathrm{~km}$ in a generally northnortheasterly direction, which is at about $45^{\circ}$ to the polje margin. During normal floods within the polje it becomes partly flooded but a continuous stream never appears in the "Main Channel". Rising water penetrates into it through vertical shafts that pierce the floor at several locations, their blind, muddy bottoms visible during times of extreme drought. Mostly flooded, and thus seldom visited, the extreme northern part of the cave continues into a completely drowned channel. The 2003 extreme drought permitted pushing of the main channel in both directions. On its southern end the terminal breakdown was reached only a few metres from the surface, where its continuation in the form of an unroofed cave is obvious. On the northern side, scuba divers have explored the flooded continuation of a several hundred metre-long new extension somewhat further, without reaching its physical end.

A number of lesser, basically phreatic, passages that branch off it soon close down in loamy chokes. Another extension (termed Logaški rov) was also found in the "Main Channel". Its beginning appears to be the continuation of the upper gallery. Further on it drops down to the flood level and displays characteristic phreatic morphology. This part of the cave has not yet been fully explored and surveyed.

Logarček's "main" passages are basically epiphreatic, whereas early phreatic imprints are better preserved

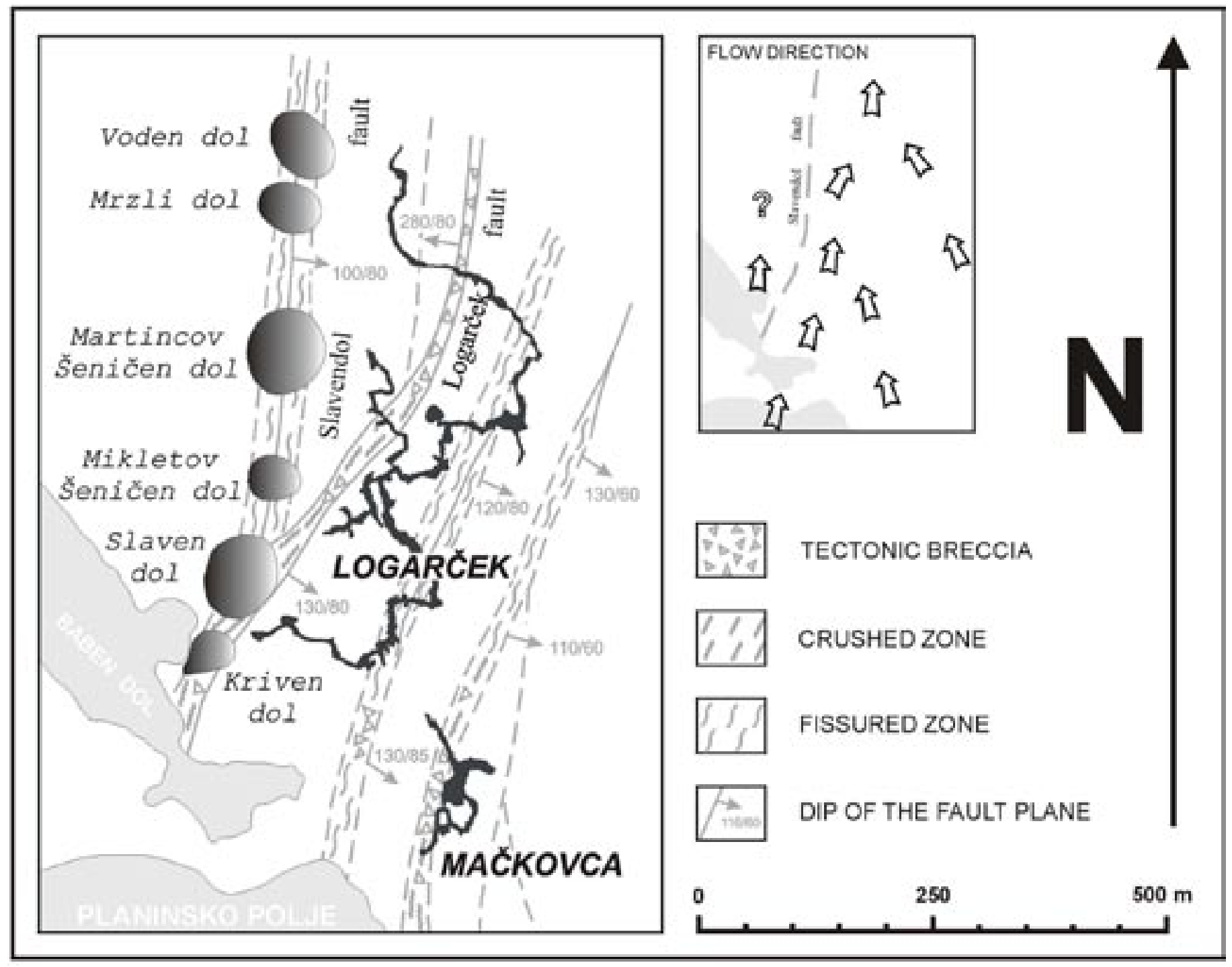

Fig.4. Geological and speleological details of the Logarček area. 
than in the other two caves considered above. This indicates that the "main" passage of Logarček was once inundated by gravel-laden water. However, if compared to Karlovice and the underground Pivka passages, this "intervention" was short, and only parts of the cave were affected.

Logarček differs from the two caves considered above in the way that the accessible passages no longer transmit the actual underground river (the Unica), and because its "Main Channel" only gives an indication of the water body within the system. In 1962, Gams stated that several independent, completely separate, streams traverse beneath the "Main Channel", approximately in a westerly direction. It appears that the passages are more or less embryonic, completely phreatic, and that one cannot yet speak about the "third" cave level ${ }^{6}$. Where closest to the surface (near Slaven dol doline) the thickness of the cave ceiling is only a few metres. As the surface elevation increases towards the northeast, the thickness of the roof above the extreme (presently known) parts reaches $100 \mathrm{~m}$. Though Logarček's "Main Channel" is much more winding than in the previous two cases, the general trend is obvious (Fig.4). It is neither parallel to the polje margin nor to the local strike. Nevertheless, the relationship with tectonic structure is clear. $50 \mathrm{~m}$ to $150 \mathrm{~m}$ west of the "Main Channel" is the fracture zone of a fault several tens of metres wide, trending at about $020-200^{\circ}$. Šušteršič et al. (2001) called it the Logarček Fault. Farther north it intercepts the "Main Channel". This location is marked by a large chamber, named the Collapse Chamber (Podorna dvorana). The ground plan of the cave reveals that several branches of the cave become impenetrable ${ }^{7}$ in the proximity of the Logarček Fault.

The only exception is Logaški rov. There, the location of the fault crossing is marked by a c. $20 \mathrm{~m}$ high/deep ${ }^{8}$ phreatic jump. There is hardly a doubt that the phreatic jump formed as a consequence of the difficulties that the water faced when trying to cross the fault. As a general rule, similar jumps (or

\footnotetext{
${ }^{6}$ During the summer 2003 drought, the watertable within the cave dropped to about $20 \mathrm{~m}$ below the usual "low water" level, and some "permanent" pools dried up. In one of them cavers were able to penetrate between boulders to enter a vertical shaft with a "lake" at its foot. A diving attempt in the muddy water revealed that the drowned vertical shaft continues downwards for more than twelve metres. This indicates that an extensive phreatic maze probably exists below the level of the "Main Channel". An additional indication of active flow in this level is provided by water temperatures in some "pools" that were measured on the same occasion.

7 The nature of the obstacles is generally obscured by massive loam deposits.

${ }^{8}$ Considering the present situation it is "deep". Šušteršič (2002), however, demonstrated that there is no reason to believe that the evolution of the caves around Planinsko polje was straightforward. One cannot guess whether the initial stream flow was opposite to or the same as the present direction.
}

collapses) also appear at critical locations in other caves in the neighbourhood. On the other hand, no collapse doline is known on the Logarček Fault, which appears to indicate that the fault differs in some aspect from those discussed above, in Postojnska jama and Karlovice.

The situations become comparable if the fault from which the Logarček Fault diverges a few hundred metres north of the polje, (Čar, 1982) is considered. It was the first fault identified in the area of the Slavendol collapse doline, and it was named the Slavendol Fault (Šušteršič et al. 2001). The known fault trace begins on the actual border of the polje and runs more or less northwards, veering a few degrees towards the east. Additional mapping revealed about $100 \mathrm{~m}$ of dextral strike-slip movement in a horizontal sense, not ruling out the possibility of a vertical component.

Comparing this situation with the former two cases, it becomes evident that the Slavendol Fault, though somewhat more remote from the known cave passages than the Logarček Fault, fits the concept of a deflector fault much better than the latter. The nature of the tectonic injuries to the rock, and the width of the Slavendol Fault zone, indicate that at the level of the present Logarček "Main Channel" the fault zone is mechanically too weak to permit the formation of larger cave chambers. This made the sinking river wind, on the upstream side, along the Slavendol Fault and caused the location of the break to shift stepwise more and more towards the north. In the horizontal plane the visible results of this route-searching are collapse dolines. Vertically the process is evidenced by the remains of the phreatic jump, presently seen as an apparently isolated "cave with shaft", lying close to the fault zone on its upstream side.

Within the trace of a wide shatter- to crush- and partly laminated-zone, there is a string of relatively "old" inactive, collapse, dolines (Figs 4,5). The volumes of most of these are so large ${ }^{9}$ that they could not have been formed just by the sudden collapse of a cave chamber. In fact, steady removal of collapsed material must have persisted long after the collapse process began. The stage reached by slope decay varies from doline to doline, testifying that they were not active at the same time. Considering the average denudation rate of $65 \mathrm{~m} \mathrm{Ma}^{-1}$ (Gams, 1966) and the expected rate of undercutting, one may expect that some of them are so old that they have become partly, or even completely, "ghost caves"10. So, it is difficult to estimate the succession of their formation. On the other hand, they are quite regularly spaced. Whether this is related to periodic oscillation

\footnotetext{
${ }^{9}$ Slaven dol: $154 \times 10^{3} \mathrm{~m}^{3}$;

Mikletov Šeničen dol: estimation $>5 \times 10^{4} \mathrm{~m}^{3}$; Martincov Šeničen dol: $126 \times 10^{3} \mathrm{~m}^{3}$; Mrzli dol: estimation < $5 \times 10^{4} \mathrm{~m}^{3}$; Voden dol: estimation $>5 \times 10^{4} \mathrm{~m}^{3}$ (Stepišnik, 2005). ${ }^{10}$ Sensu Šušteršič (1999a) these are "phantom caves". However, considering that this term has been used in different contexts by other authors, the alternative and less ambiguous expression "ghost cave" is now proposed for future use, to avoid confusion.
} 


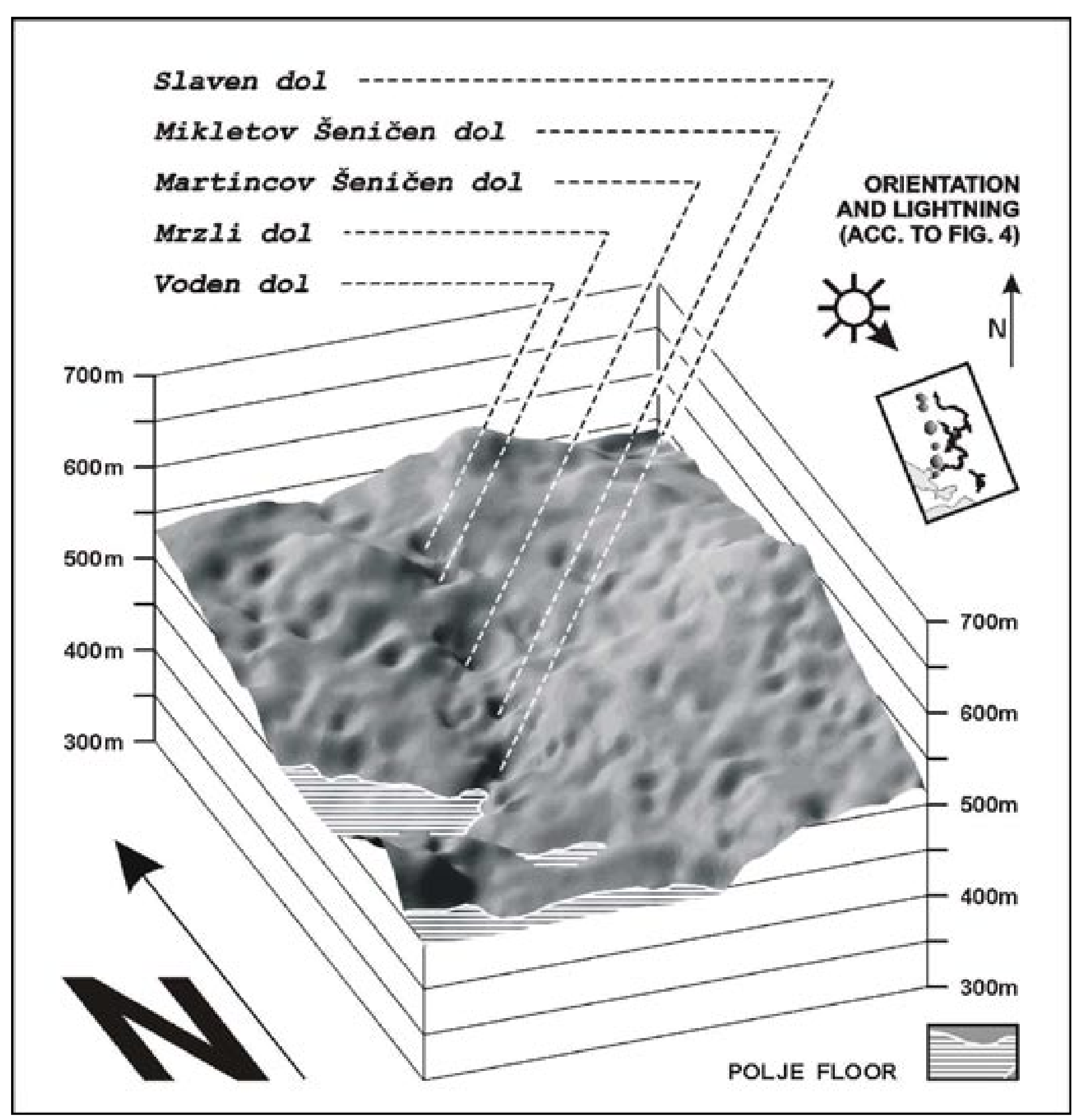

Fig.5. Panoramic view (DEM) of the Fig. 4 area. Note that other than the (marked) collapse dolines only larger solution dolines are displayed. Cave features and structural elements are omitted due to undulating surface relief. (Orthographic picture; grid $18 \mathrm{~m} \times 18 \mathrm{~m}$; field of view: $45^{\circ}$; rotation: $339^{\circ}$, tilt: $30^{\circ}$; horizontal lightning: $135^{\circ}$; vertical lightning: $45^{\circ} /$ all horizontal angles measured clockwise, starting at North.)

of fault zone cementation (as revealed on the surface) cannot be guessed until the fault has been reached in the cave.

Farther from the polje the string of collapses ends. As the surface elevation is increasing (Fig.5), the explanation that the rock mass above the cave has become too thick to allow collapse appears attractive. However, the volumes of the dolines do not confirm this, as the quantity of rock removed is so large that collapse would nevertheless have reached the surface. However, the possibility that the mechanical properties of the fault have changed spatially to such an extent (Čar and Gospodarič, 1985) that the cave roof is more stable, cannot be excluded. Additionally, increasing distance from the Idria Fault zone could have brought about a similar effect. Both options might potentially be involved. (Čar and Gospodarič, 1985).

Nevertheless, considering the hydrology of the Logarček cave discussed above, it is evident that the modern collector channel, though not yet fully developed, must lie between the "Main Channel" and the Slavendol Fault. 


\section{DISCUSSION}

Development of "active" collapse dolines and the consequent concentration of channels parallel to certain faults reflect the "difficulties" that water has faced when encountering the fracture zones of a deflector fault. Thus, collector channels can appear only on the upstream side of such obstacles. The exact mechanism of concentration is best displayed in the case of the Karlovice cave system (Fig.3), where the obstacle runs perfectly parallel to the outlet polje margin.

The example of Postojnska jama is rather less obvious, as the polje floor is not in karstic rock, but in flysch. Nevertheless, the present contact, though basically stratigraphical, has been strongly reworked tectonically. The slightly upwarped, impermeable, rim of the flysch area leads to water collecting mostly on the surface, and the collector channel is fed from the surface only by sparse but well-defined tributaries. As in the case of Karlovice, the collector channel runs parallel to the polje margin and the tributaries are more or less perpendicular to both.

The situation is somewhat different in the case of Logarček. The angle between the polje border and the general direction of the cave is nearly $45^{\circ}$. The "Main Channel" appears to be a partly abandoned collector channel, whereas the present collector channel is, perhaps, just being formed. Similarities are better expressed by considering the relationship (parallelism) between the collector channel and the deflector fault (marked by collapse dolines). Relatively uniform cave channels meander approximately parallel to the fault zone, and upstream tributaries join it (or presently cross it) at a gentle angle (Fig.4).

Additionally, Logarček is crossed by a swarm of faults (the Logarček Fault and various unnamed fractures lying farther to the east). They have largely impeded the flow but they did not influence the arrangement of the cave passages. This indicates that the guidance was selective, in the sense that older faults guided the general direction of the flow corridor, whereas the younger ones influenced only the arrangement of particular channels.

Karstification attacks tectonically damaged zones within the karstifiable rock, too, and the zones' properties change with time (Čar, 1982). In some places they are re-cemented, elsewhere they may become even more transmissive. The degree of change evidently depends upon the time that has elapsed since their formation or, perhaps more accurately, since active tectonism ceased. Thus, it would be expected that older faults should be more diverse, in the sense of highly transmissive portions alternating

${ }_{11}$ The largest one in the Ljubljanica catchment, named Laška kukava, exceeds $4 M \mathrm{~m}^{3}$, whereas the average appears to be several hundred thousand $\mathrm{m}^{3}$ (Šušteršič, 2000b). However, features smaller than a few thousand $m^{3}$ are hardly distinguishable from other types of closed depressions within the karst surface. with virtually impermeable segments. Distribution of attempted breakthrough locations and collapse dolines in the cases of Karlovice and of Logarček might reflect uneven, but spatially regular "karstification" of the broken zones. In the case of the possibly younger fault at Postojnska jama the process might not have proceeded so far.

The relationship of the proximity/distance between collector channels and deflector faults should not be overlooked. In the case of Postojnska jama they are almost adjacent, whereas the distance is the greatest in the case of Logarček. It seems that the amplitudes of winding of the collector channels increase in line with increased distance between the collector channel and the deflector fault. However, until more field examples are studied, this should be noted simply as an incidental observation. Until more field examples have been studied to a similar level of detail, the present findings should be considered more as an explanation of particular situations than as a general rule.

Considering that early measurements of water hardness on the upstream and downstream sides of some collapse dolines yielded no noticeable differences, the impressive volumes ${ }^{11}$ of some active collapse dolines, exceeding the possible volume of any cave chamber by many times, give an impression that they are a product of rather obscure, long term, processes. In some cases, say Planinska Koleševka (Gospodarič 1976; Šušteršič et al., 2002) mechanical removal of Pleistocene cryoclastic gravel has been detected and well documented (o.c.). In some other cases, however (Šušteršič, 1997), this explanation does not appear to be correct and other solutions were sought. On the basis of the minimum possible discharge the same author (2003) calculated the mass budget in Rakovska Kukava, only a few kilometres distant from Logarček. It transpired that the post-Pleistocene removal of the scree in the centre of the doline could have happened with only a $0.016 \mathrm{mg} \mathrm{l}^{-1}$ increase of dissolved $\mathrm{CaCO}_{3}$ content in the stream, values that are beyond the limit of typical field measurement techniques. If generalized to the entire doline volume, and even disregarding the probability of larger discharges in the past, only a few hundred thousand years would suffice to form the whole doline $\left(1.35 \mathrm{M} \mathrm{m}^{3}\right)$. This means that the processes bringing about the formation of "active" collapse strings and collector channel formation are relatively rapid. More basically, it becomes clear why the collector channels can form at all. Otherwise, the regional change of the water table elevation (which is supposed to be slower) would thwart the arrangement of the cave passages into the collector channel, because if development of the collector channel were slower the gradual changes in the water table would dry up the channel before development was complete. 


\section{CONCLUSIONS}

- The collector channel is a positively defined element of the cave system with its own, specific individuality. It is connected causally with geological/ tectonic structure and hydrogeological conditions within speleogenetic space.

- The collector channel is formed as a result of channel system reorganisation, and is a consequence of the presence of a less permeable and less stable fault zone perpendicular to the hydraulic gradient direction.

- Nevertheless, some locations must initially have sufficient transmissivity perpendicular to the fault zone, so that the flow corridor does not form in a completely different direction.

- Due to its hydrogeological and speleogenetic role, the fault that brings about the formation of the collector channel is termed a deflector fault.

- The collector channel gathers underground streams that should cross the tectonically injured zone of the deflector fault. However, the latter generally does not let them through, and instead it deflects them laterally.

- In cases where the deflector fault is close enough to the polje, sinking water joins it directly and the statement that collector channels run parallel to the polje margin holds true. However, the logical link is indirect.

- All three of the studied collector channels are epiphreatic, though none of them has developed a completely tunnel-like shape.

- Transformation of a fractured flow corridor into a conduit pattern is not guided only by local effects. Control is not only passive, and the passage pattern is not just a network of enlarged fissures.

- The mere existence of a (potential) deflector fault will (a) influence the choice of the proto-channels that will be further enlarged and (b) collapse due to conduit formation influenced the further development of the system. Thus, during cave system formation, any negative feedback processes that appear can guide the arrangement of the channel maze towards a predictable pattern.

\section{ACKNOWLEDGEMENTS}

The author thanks his colleagues Drs Jože Čar and Stanka Šebela for the opportunity of putting the data of various sources together, and for fruitful discussions when developing the fundamental ideas. Dr Art Palmer is thanked for his encouraging comments. Dr Franci Gabrovšek is thanked for his important comments on the initial calculations about active collapse doline dynamics. The active cavers Jože Košir, Tone Palčič and Jože Pristavec are thanked for access to as yet unpublished data about the recent discoveries in Logarček cave. Finally, thanks to Dr David J. Lowe for smoothing the raw English text and for the linguistic advice that made the ideas presentable to the international scientific community.ù

\section{REFERENCES}

Čar J., 1982 - Geologic setting of the Planinsko polje ponor area (In Slovene, English Summary). Acta Carsologica, 10: $75-105$.

Čar J. \& Gospodarič R., 1984 - About geology of karst among Postojna, Planina and Cerknica (In Slovene, English Summary). Acta Carsologica 12: 91-106.

Čar J. \& Šebela S., 1997 - Structural position of vertical karst objects on Postojnska Gmajna. Acta Carsologica 26( 2): 295-314.

Cramer H., 1944 - Die Systematik ser Karstdolinen. Neues Jahrbuch für Mineralogie, Geologie und Paläontologie; Beilage Band, Abt. B, 85: 293-382.

Ford D.C. \& Williams P.W., 1989 - Karst geomorphology and hydrology. London: Unwin Hyman $601 \mathrm{p}$.

Gabrovšek F., 2000 - Evolution of early karst aquifers: from simple principles to complex models. Ljubljana: $150 \mathrm{p}$.

Gams I., 1962 - Logarček (In Slovene, English Summary). Acta Carsologica, 3: 1-84.

Gams I., 1965 - On the Quarternary geomorphogenesis of the area among the karst poljes of Postojna, Planina and Cerknica (In Slovene, English Summary). Geografski vestnik 37: 61-101.

Gams I., 1966 - Factors and dynamics of corrosion of the carbonatic rocks in the Dinaric and Alpine karst of Slovenia (In Slovene, English Summary). Geografski vestnik, 38: 11-68.

Gospodarič R., 1970 - Speleological investigations of the Cerknica cave system (In Slovene, English Summary). Acta Carsologica, 5: 109-169.

Gospodarič R., 1976 - The Quaternary caves development between the Pivka basin and Polje of Planina (In Slovene, English Summary). Acta Carsologica, 7: 8-135.

Habič P., 1967 - Nova odkritja $v$ Veliki Karlovici (= New discoveries in Velika Karlovica / in Slovene only). Naše jame, 9: 52-54.

Klimchouk A. B. \& Ford D. C., 2000- Types of Karst and Evolution of Hydrogeologic Setting. In: Klimchouk A., Ford D., Palmer A. \& Dreybrodt W. (Eds), Speleogenesis: Evolution of karst aquifers. Huntsville: National Speleological Society, 45-53.

Klimchouk A. B., Ford D. C., Palmer A. N. \& Dreybrodt W. (Eds), 2000 - Speleogenesis: Evolution of Karst Aquifers. Huntsville, AL: National Speleological Society, 527 p.

Lauritzen S.E. \& Lundberg J., 2000 - Solutional and erosional morphology. In: Klimchouk A., Ford D., Palmer A. \& Dreybrodt W. (Eds), Speleogenesis: Evolution of karst aquifers. Huntsville: National Speleological Society, 408-426.

Lowe D.J., 1993 - Forest of Dean inception horizons. Cave Science 20(2): 31-43. 
Lowe D.J., 2002 - Stratigraphical-guided drainage in the Slaughter catchment, Forest of Dean, UK: an interim report. Cave and Karst Science, 29(3): 125-128.

Michler I. \& Hribar F., 1959 - Contribution à la connaissance de la Pivka souterraine (In Slovene, French Summary). Acta Carsologica, 2: 157-195.

Palmer A.N., 2000 - Hydrogeologic control of cave patterns. In: Klimchouk A., Ford D., Palmer A. \& Dreybrodt W. (Eds), Speleogenesis: Evolution of karst aquifers. Huntsville: National Speleological Society, 77-90.

Sauro U., 2005 - Closed depressions. In: Culver D.C. and White W.B. (Eds.) Encyclopedia of caves. Elsevier, 654 pp. Amsterdam.

Šebela S., 1998 - Tectonic structure of Postojnska jama cave system. Ljubljana, Založba ZRC, 18: 112 p.

Šebela S. \& Čar J., 1991 - Geological setting of collapsed chambers in Vzhodni rov in Predjama cave (In Slovene, English Summary). Acta Carsologica, 20: 205-222.

Šušteršič F., 1979 - Some principles of the cave profiles simulation. In: Actes du symposium international sur l'érosion karstique: Aix-en-Provence-MarseilleNîmes 10-14 Septembre 1979, (Mémoire, no. 1). Nîmes: Association Française de Karstologie: Museum d'Histoire Naturelle, 1979, 125-131.

Šušteršič F., 1997 - Rakovska kukava-collapse or tumour doline? Acta Carsologica, 27(1), 231-259.

Šušteršič F., 2000a - Speleogenesis in the Ljubljanica river drainage basin, Slovenia. In: Klimchouk A., Ford D., Palmer A. \& Dreybrodt W. (Eds), Speleogenesis: Evolution of karst aquifers. Huntsville: National Speleological Society, 397-406.
Šušteršič F., 2000b - Are "collapse dolines" formed only by collapse? Acta Carsologica, 29(2), 251-289.

Šušteršič F., 2002 - Where does the underground Ljubljanica flow? Materials and Geoenvironment (RMZ), 49(1): 61-84.

Šušteršič F., 2003 - Collapse dolines, deflector faults and collector channels. Speleogenesis and evolution of karst aquifers, 1(3), www.speleogenesis.info, $10 \mathrm{p}$.

Šušteršič F., Čar J. \& Šebela, S., 2001 - Collector channels and deflector faults (In Slovene, English Summary). Naše jame, 43: 8-22.

Šušteršič F., Šušteršič S. \& Stepišnik U., 2002 - Late pleistocene redirection of the Cerkniščica river: effect on the neighbouring karst. In: Gabrovšek F. (Ed.). Evolution of karst: from prekarst to cessation (Carsologica). Postojna: Inštitut za raziskovanje krasa ZRC SAZU; Ljubljana: Založba ZRC, pp. 283-298.

Vrabec M. \& Fodor L. 2005 - Late Cenozoic tectonics of Slovenia: Structural styles at the northeastern corner of the Adriatic microplate. In: N. Pinter, G. Grenerczy, J. Weber, D. Medak \& S. Stein (Eds.): The Adria Microplate: GPS Geodesy, Tectonics, and Hazards. Kluwer Academic Publishers. Preprint, 1-18.

Zupan Hajna N., 1995 - Mineral composition of loams from different types of fault zones on Karst. In: Vlahović I. Velić I. \& Šparica M. (Eds.). 2000. Zbornik radova, Institut za geološka istraživanja, 657-660.

Žalec P., Vrhovec T., Mihailovski M., Zwölf D. \& Drole F., 1997 - Jamski sistem Zelške jame-Karlovica [Cave system Zelške jame-Karlovica / in Slovene only]. Naše jame, 39: 87-94 